\title{
Growth and yield of sweet potato in response to the application of nitrogen rates and paclobutrazol
}

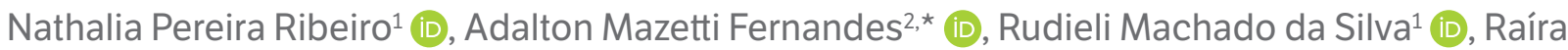 \\ Andrade Pelvine ${ }^{1}$ (D), Natália Silva Assunção ${ }^{1}$ (D) \\ 1. Universidade Estadual Paulista "Júlio de Mesquita Filho" - Faculdade de Ciências Agronômicas - Botucatu (SP), Brazil. \\ 2. Universidade Estadual Paulista “Júlio de Mesquita Filho” - Centro de Raízes e Amidos Tropicais - Botucatu (SP), Brazil. \\ Received: Oct. 21, 2020 | Accepted: May 3, 2021 \\ Section Editor: Osvaldo Guedes Filho \\ *Corresponding author: adalton.fernandes@unesp.br \\ How to cite: Ribeiro, N. P., Fernandes, A. M., Silva, R. M., Pelvine, R. A. and Assunção, N. S. (2021). Growth and yield of sweet potato in \\ response to the application of nitrogen rates and paclobutrazol. Bragantia, 80, e3821. https://doi.org/10.1590/1678-4499.20200447
}

\begin{abstract}
The excess of nitrogen $(\mathrm{N})$ causes the overgrowth of sweet potato foliage, increasing the self-shading and reducing the root yield. Therefore, a combined $\mathrm{N}$ and paclobutrazol (PBZ) application can reduce the vegetative overgrowth and benefit the sweet potato yield. The purpose of this study was to evaluate the plant growth, yield, uptake and removal of $\mathrm{N}$ by sweet potato plants fertilized with $\mathrm{N}$ and treated with PBZ during two planting seasons. The treatments consisted of four $\mathrm{N}$ rates $\left(0,50,100\right.$ and $\left.200 \mathrm{~kg} \cdot \mathrm{ha}^{-1}\right)$, three forms of PBZ application (PBZ-10: PBZ applied at 10 days after side-dressing N fertilization [DASNF]; PBZ-25: PBZ applied at 25 DASNF, and PBZ-10 + 25: PBZ applied at 10 plus 25 DASNF), and a control (without PBZ application). Paclobutrazol application temporarily reduced the length of the main branches of sweet potato planted in the rainy season, but it did not reduce the shoot biomass of plants in both planting seasons. A single application of PBZ at 10 DASNF increased the yield of fresh storage roots in the two planting seasons, but, during the rainy season, the increases were greater when two applications were carried out. The application of $50 \mathrm{~kg} \cdot \mathrm{ha}^{-1} \mathrm{~N}$ in the rainy season was sufficient to reach the maximum yield of fresh storage roots, but, in the dry season, the $\mathrm{N}$ fertilization increased the $\mathrm{N}$ uptake without benefiting the root yield.
\end{abstract}

Key words: nitrogen uptake; triazole; gibberellin inhibitor; planting seasons; Ipomoea batatas (L).

\section{INTRODUCTION}

Despite being considered as a rustic crop, the sweet potato uptakes large amounts of nutrients from the soil, and nitrogen (N) is the second nutrient most taken up by this root crop (Fernandes et al. 2020). In sweet potato, $\mathrm{N}$ influences the production and distribution of biomass in the plants and improves the yield of the harvested storage roots (Duan et al. 2019; Kakabouki et al. 2020).

In Brazil, $\mathrm{N}$ fertilization recommendations for sweet potatoes indicate rates between 20 and $60 \mathrm{~kg} \cdot \mathrm{ha}{ }^{-1} \mathrm{~N}$ (Casali 1999; Lorenzi et al. 1997; Silva et al. 2002), but these recommendations were based on studies carried out with old cultivars, which present low yield, and without considering the cultivation history of the field (Fernandes et al. 2018). Recent studies with more productive sweet potato cultivars have shown responses to $\mathrm{N}$ rates ranging from 102 to $183 \mathrm{~kg} \cdot \mathrm{ha}^{-1}$ (Foloni et al. 2013; Leonardo et al. 2014; Oliveira et al. 2006; Santos Neto et al. 2017). However, there is a concern regarding the application of high $\mathrm{N}$ rates in the sweet potato crop. The excess of $\mathrm{N}$ increases the leaf area index, decreases the development of the storage roots and the harvest index (HI), favoring the growth of the vegetative organs, in addition to prolonging the cultivation cycle (Fernandes et al. 2018; 2020). Therefore, avoiding excessive vegetative growth is important to obtain high yield.

The use of plant growth regulators is an approach to reduce the overgrowth of the shoot of plants (Mabvongwe et al. 2016). In sweet potatoes, the application of prohexadione-calcium was efficient in reducing the length of the branch and increasing the total storage root yield (Njiti et al. 2013). The use of paclobutrazol (PBZ) has also shown some positive effects on the quality of the sweet potato roots (Chen et al. 2012). Paclobutrazol is a synthetic chemical compound that acts by 
inhibiting the synthesis of the gibberellin (GA) in the endoplasmic reticulum and controlling the vegetative overgrowth of plants (Rademacher 2015). This plant growth regulator is widely used in Brazilian conditions to induce mango flowering (Oliveira et al. 2017). In addition, PBZ has been used to control excessive shoot growth of other crops, such as soybeans (Pricinotto and Zucarelli 2014), wheat (Espindula et al. 2009), and tomato (Silva and Faria Junior 2011).

Although research indicates that PBZ can assist in the management of several crops (Chen et al. 2012; Espindula et al. 2009; Oliveira et al. 2017; Pricinotto and Zucarelli 2014; Rademacher 2015; Silva and Faria Junior 2011), the Brazilian recommendations for the use of $\mathrm{PBZ}$ are still restricted to mango, tomato, and avocado crops (Brazil 2021). Thus, as sweet potato has a high production of branches and a relatively low $\mathrm{HI}$, it is possible that the combined application of $\mathrm{N}$ and PBZ in sweet potato could alter the partition of carbohydrates in the plant and favor the yield of storage roots. Thus, the objective of this study was to evaluate the plant growth, storage root yield, and the uptake and removal of $\mathrm{N}$ by sweet potato plants fertilized with $\mathrm{N}$ and treated with PBZ during two planting seasons.

\section{MATERIAL AND METHODS}

Four field experiments were carried out between 2017 and 2019. Two experiments were implemented during the rainy season (October 2017 and October 2018), and the other two during the dry season (May 2018 and June 2019). Three of the experiments were carried out in different areas of the São Manuel Experimental Farm of the College of Agricultural Science of the São Paulo State University $\left(22^{\circ} 25^{\prime} \mathrm{S}, 48^{\circ} 34^{\prime} \mathrm{W}\right.$; and $740 \mathrm{~m}$ a.s.l.). The experiment planted in May 2018 was the only one carried out in a commercial sweet potato production area in the municipality of Bauru - SP $\left(22^{\circ} 21^{\prime} \mathrm{S}, 49^{\circ} 16^{\prime} \mathrm{W}\right.$; and $539 \mathrm{~m}$ a.s.l.). The soil of both areas was classified as sandy-textured Dystroferric Red Latosols (Oxisols) (Santos et al. 2018). During the conduction of the experiments, the maximum and minimum temperatures, and the average rainfall of each studied site were monitored (Fig. 1).
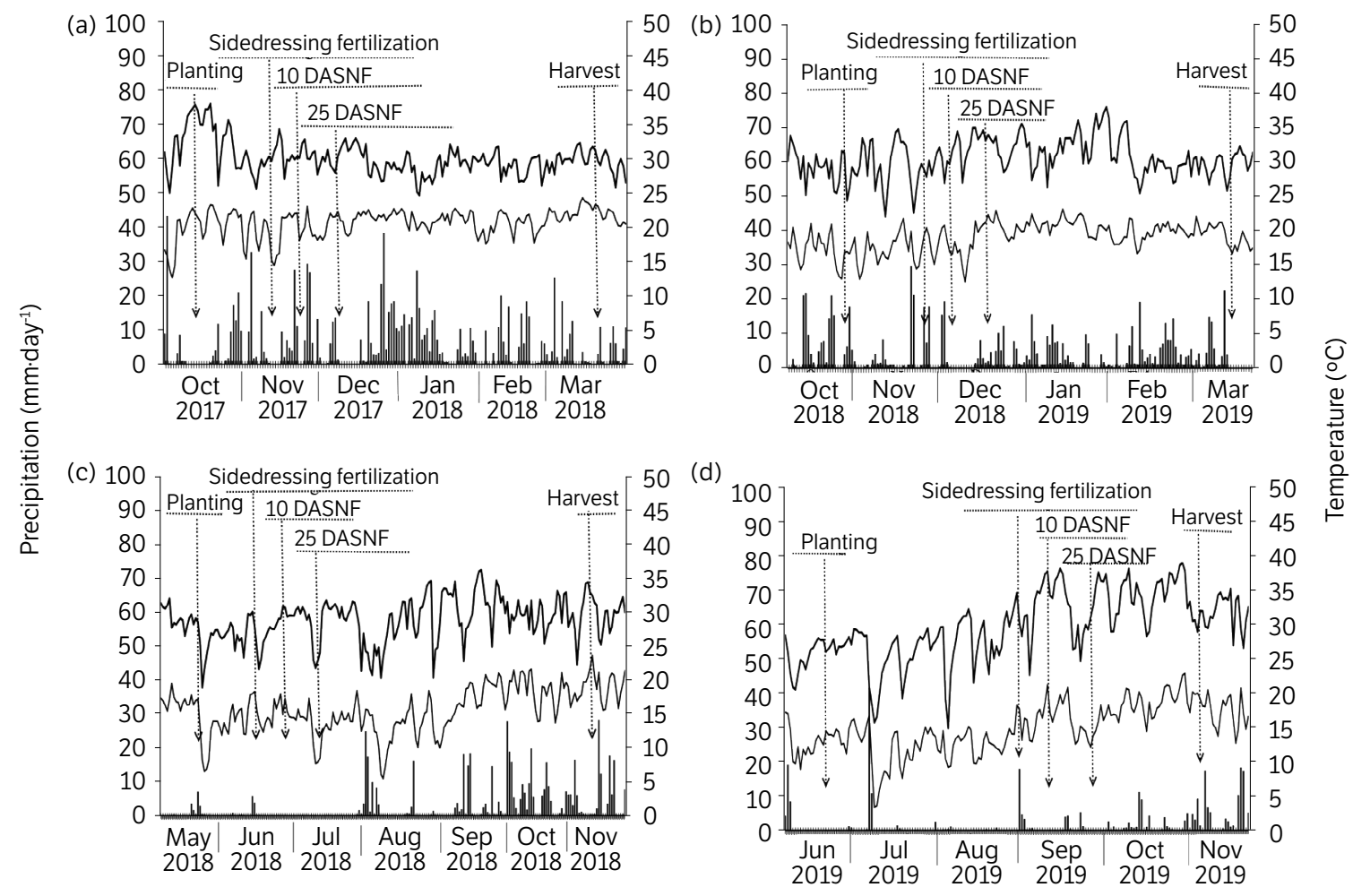

Figure 1. Daily rainfall (bars) and maximum and minimum temperatures (thick and thin lines, respectively) recorded in the experimental areas during the sweet potato cultivation.

Note. (a) and (b) are rainy season planting of São Manuel in 2017/18 and 2018/19, respectively. (c) and (d) are dry season planting of Bauru in 2018 and São Manuel in 2019, respectively. 
A randomized blocks experimental design with a $4 \times 4$ factorial scheme, and four replications, was used for the experiments. The treatments consisted of four $\mathrm{N}$ rates $\left(0,50,100\right.$ and $\left.200 \mathrm{~kg}^{-h a^{-1}}\right)$ combined with three forms of PBZ application (PBZ-10: PBZ applied at 10 DASNF; PBZ-25: PBZ applied at 25 DASNF; and PBZ-10 + 25: PBZ applied at 10 plus 25 DASNF), and a control (without PBZ application). The $\mathrm{N}$ rates for each treatment were split applied, being half the $\mathrm{N}$ rate applied at planting and the remainder as sidedressing fertilization using urea $(45 \% \mathrm{~N})$. Each plot was represented by four $4 \mathrm{~m}$-long rows of sweet potatoes. The analysis area of each plot was represented by the two central rows, disregarding $0.5 \mathrm{~m}$ at the end of both rows within the plots. The commercial product Cultar 250 SC was used as the source of PBZ, at a rate of $100 \mathrm{~g}^{-h a^{-1}}$ active ingredient (a.i.) at each application.

Before the sweet potato planting, soil samples were collected at a depth of 0-0.20 $\mathrm{m}$ in order to determine the chemical characteristics of each experimental area (van Raij et al. 2001). In the 2017 and 2018 rainy season plantings (São Manuel), the results of the soil analyzes were: $\mathrm{pH}\left(\mathrm{CaCl}_{2}\right) 5.2$ and 4.7; 21 and $12 \mathrm{~g} \cdot \mathrm{dm}^{-3}$ Organic matter (O.M.); 23 and $5 \mathrm{mg} \cdot \mathrm{dm}^{-3} \mathrm{P}_{\text {resin-extractable' }}$; 0.57 and $0.91 \mathrm{mmolc} \cdot \mathrm{dm}^{-3} \mathrm{~K} ; 9$ and $14 \mathrm{mmol}_{c} \cdot \mathrm{dm}^{-3} \mathrm{Ca} ; 6$ and $7 \mathrm{mmol}_{c} \cdot \mathrm{dm}^{-3} \mathrm{Mg} ; 29$ and $43 \mathrm{mmol} \cdot \mathrm{dm}^{-3}$ cation exchange capacity (CEC), and 54 and 50\% base saturation (BS), respectively. In the 2018 (Bauru) and 2019 (São Manuel) dry season plantings the results were: $\mathrm{pH}\left(\mathrm{CaCl}_{2}\right) 4.4$ and 5.1; 13 and $12 \mathrm{~g} \cdot \mathrm{dm}^{-3} \mathrm{O} . \mathrm{M} . ; 19$ and $29 \mathrm{mg} \cdot \mathrm{dm}^{-3} \mathrm{P}_{\text {resin-extractable }} ; 1.24$ and $0.95 \mathrm{mmol} \cdot \mathrm{dm}^{-3} \mathrm{~K} ; 5$ and $22 \mathrm{mmol}_{c} \cdot \mathrm{dm}^{-3} \mathrm{Ca} ; 4$ and $5 \mathrm{mmolc} \cdot \mathrm{dm}^{-3} \mathrm{Mg} ; 33$ and $52 \mathrm{mmol}_{c} \cdot \mathrm{dm}^{-3} \mathrm{CEC}$, and 31 and $56 \% \mathrm{BS}$, respectively.

The soil preparation was carried out conventionally with a disc plowing and a light harrowing. The day before planting, $30-\mathrm{cm}$ high ridges were built, in which $10-\mathrm{cm}$ deep furrows were made for fertilization. The planting fertilization was carried out with 80 and $100 \mathrm{~kg} \cdot \mathrm{ha}^{-1} \mathrm{P}_{2} \mathrm{O}_{5}$ in the rainy season plantings of 2017 and 2018, respectively. In the dry season, the P rate of $60 \mathrm{~kg} \cdot \mathrm{ha}^{-1} \mathrm{P}_{2} \mathrm{O}_{5}$ was used for both 2018 and 2019 plantings. About $90 \mathrm{~kg} \cdot \mathrm{ha}^{-1} \mathrm{~K}_{2} \mathrm{O}$ were applied in each experiment. Triple superphosphate $\left(41 \% \mathrm{P}_{2} \mathrm{O}_{5}\right.$ and $\left.7 \% \mathrm{Ca}\right)$ and potassium chloride $\left(60 \% \mathrm{~K}_{2} \mathrm{O}\right)$ were used as sources $\mathrm{P}$ and $\mathrm{K}$. After distribution in the soil, the fertilizers were incorporated into the planting furrows, and the sweet potato was planted afterward with moist soil.

The rainy season plantings took place on October $13^{\text {th }}, 2017$ and October $22^{\text {nd }}, 2018$, while the dry season plantings took place on May $19^{\text {th }}, 2018$ and June $16^{\text {th }}, 2019$. Only in the dry season plantings, irrigations were carried out with $3.0 \mathrm{~L}$ of water per plant in the first two weeks of cultivation, in order to ensure the setting of the branches.

The branches used for planting were collected one day before planting, from the apex of young plant matrices of the cultivar 'Canadense', and sectioned into pieces of approximately $30 \mathrm{~cm}$ in length. One branch was used per planting pit, burying 3 to 4 internodes from the base of the branches (Oliveira et al. 2006). The plant spacing of $1.0 \times 0.30 \mathrm{~m}$ was used for the rainy season planting of 2017, while in the other planting seasons the spacing of $1.3 \times 0.30 \mathrm{~m}$ was adopted.

The side-dressing $\mathrm{N}$ fertilization, with the remainder $50 \%$ of the $\mathrm{N}$ rates of each treatment, was carried out at 30 days after planting (DAP) in both plantings of the rainy seasons, and the dry season planting of 2018. In the dry season planting of 2019 (São Manuel), the side-dressing N fertilization was applied at 77 DAP due to the lack of rainfall (Fig. 1d).

Paclobutrazol was sprayed via leaf using a volume of $200 \mathrm{~L} \cdot \mathrm{ha}^{-1}$ of solution at 10 and 25 DASNF in all experiments. During the crop development period, all recommended agricultural practices, such as weeding, irrigation, and pest control, were carried out according to the need of the crop.

The sweet potato harvest took place in March 2018 and 2019 for the rainy season plantings ( 153 DAP) and in November 2018 and 2019 for dry season plantings ( 160 DAP).

At 10 ( $1^{\text {st }}$ evaluation) and 30 ( $2^{\text {nd }}$ evaluation) days after the last application (DALA) of PBZ, the number of the main and secondary branches per plant, the length of the main branch, and the number of leaves per plant were evaluated. The number of the main and secondary branches, and the number of leaves per plant, were obtained by counting each structure in the plants. The main branches were those that originated from the base of plants, and the secondary branches were those that originated from the main branches. The length of the main branch was considered as the distance between the base of the plant and the apex of each branch.

At harvest, the final plant population was determined in two $1.5-\mathrm{m}$ long rows of each plot. After that, the plants were harvested and separated in shoot and storage roots, and then weighed (fresh weight). The yield of fresh storage roots was calculated considering the final plant population and the fresh weight of storage roots per plant. Samples of shoot and storage roots were collected, weighed (fresh weight), and dried in an oven with forced air circulation at $65^{\circ} \mathrm{C}$ until constant weight.

After drying, the samples were weighed (dry weight), and the dry matter (DM) concentration of both plant parts was calculated. The amounts of DM accumulated in both plant parts was calculated with the data of fresh shoot and storage root 
yield, and the concentration of DM in each of these plant parts. The DM of the whole plant was obtained by the sum of the DM of shoot and the storage roots. The HI was calculated by dividing the storage root DM by the whole plant DM. The dried samples were ground to pass through a 1-mm screen, and the $\mathrm{N}$ concentration was determined (Malavolta et al. 1997). The amounts of $\mathrm{N}$ accumulated in the shoot and the storage roots were obtained by multiplying the $\mathrm{N}$ concentration by the amount of DM accumulated in each plant structure. The amounts of $\mathrm{N}$ taken up by the sweet potato plants resulted from the sum of the amounts of $\mathrm{N}$ in both plant parts. The removal of $\mathrm{N}$ was represented by the amount of $\mathrm{N}$ present in the storage roots.

The data were analyzed using the SISVAR software (Ferreira 2011). A combined analysis of variance (ANOVA) using the two years revealed that there were no significant interactions between years and planting season for almost all measured variables. Therefore, the data were combined across the two years and individual ANOVAs were performed separately for each planting season. The forms of PBZ application were compared by the LSD test ( $\mathrm{p} \leq 0.05)$, and the effects of the $\mathrm{N}$ rates were analyzed by regression, being selected the significant regression equations with the highest coefficients of determination.

\section{RESULTS AND DISCUSSION}

In both planting seasons, the treatments did not influence the number of main branches per plant during the two evaluations, whose average values were between 1.4 and 1.2 branches per plant for the rainy and dry seasons, respectively (Table 1). The length of the main branches at the first evaluation (10 DALA) of the rainy season was influenced by PBZ applications and N rates, whereas in the dry season there was only a PBZ effect on this variable (Table 1). During the rainy season, the length of the branches of the PBZ-10 treatment was 9\% lower than the other treatments, which confirms the efficiency of PBZ in controlling the vegetative growth of plants, especially in countries with warmer climates (Rademacher 2015). However, in the dry season, the length of the branches did not differ among the PBZ-treated plants, but these treatments showed branches $8 \%$ longer than in the plants of the control. During the rainy season, the $\mathrm{N}$ fertilization increased the length of the branches up to $134 \mathrm{~kg} \cdot \mathrm{ha}^{-1} \mathrm{~N}$ in the first evaluation (Fig. 2a). Thus, $\mathrm{N}$-unfertilized plants showed branches $26 \%$ shorter than plants fertilized with the optimal $\mathrm{N}$ rate (Fig. 2a).

Table 1. Number of main and secondary branches per plant, length of main branches, and number of leaves per plant in two evaluation times ( $1^{\text {st }}$ and $2^{\text {nd }}$ evaluation: 10 and 30 DALA) of sweet potato in response to the application of PBZ and $\mathrm{N}$ rates during two planting seasons. Average of two planting seasons (2017/18 and 2018/19).

\begin{tabular}{|c|c|c|c|c|c|c|c|}
\hline \multirow{3}{*}{ Variables } & \multicolumn{4}{|c|}{ Time of PBZ application ${ }^{(1)}$} & \multicolumn{3}{|c|}{ ANOVA $(P>F)$} \\
\hline & Control & PBZ-10 & PBZ-25 & PBZ-10 + 25 & PBZ & N rate & $\mathrm{PBZ} \times \mathbf{N}$ \\
\hline & \multicolumn{7}{|c|}{ Rainy season planting at $1^{\text {st }}$ evaluation } \\
\hline Number of main branches per plant (No.) & $1.4 a$ & $1.6 a$ & $1.4 a$ & $1.4 a$ & ns & ns & ns \\
\hline Length of main branches $(\mathrm{cm})$ & $55.7 a b$ & $51.1 c$ & $57.3 a$ & $54.7 \mathrm{~b}$ & $<0.001$ & $<0.001$ & ns \\
\hline Number of secondary branches per plant (No.) & $5.2 b$ & $5.3 b$ & $5.4 a b$ & $5.8 a$ & 0.039 & $<0.001$ & ns \\
\hline \multirow[t]{2}{*}{ Number of leaves per plant (No.) } & $100.0 a$ & $97.8 a$ & $98.5 a$ & $102.4 a$ & ns & $<0.001$ & ns \\
\hline & \multicolumn{7}{|c|}{ Rainy season planting at $2^{\text {nd }}$ evaluation } \\
\hline Number of main branches per plant (No.) & $1.4 a$ & $1.5 a$ & $1.3 a$ & $1.4 a$ & ns & ns & ns \\
\hline Length of main branches $(\mathrm{cm})$ & $81.6 a$ & $81.2 a$ & $81.0 a$ & $80.4 a$ & ns & $<0.001$ & $<0.001$ \\
\hline Number of secondary branches per plant (No.) & $6.0 \mathrm{~b}$ & $6.2 b$ & $6.9 a$ & $7.0 a$ & $<0.001$ & $<0.001$ & ns \\
\hline \multirow[t]{2}{*}{ Number of leaves per plant (No.) } & $136.7 b$ & $157.4 a$ & $141.3 b$ & $166.4 a$ & $<0.001$ & $<0.001$ & ns \\
\hline & \multicolumn{7}{|c|}{ Dry season planting at $1^{\text {st }}$ evaluation } \\
\hline Number of main branches per plant (No.) & $1.3 a$ & $1.2 a$ & $1.2 a$ & $1.3 a$ & ns & ns & ns \\
\hline Length of main branches $(\mathrm{cm})$ & $53.4 b$ & $58.4 a$ & $58.2 a$ & $56.8 a$ & $<0.001$ & ns & ns \\
\hline Number of secondary branches per plant (No.) & $4.2 c$ & $4.4 c$ & $4.8 \mathrm{~b}$ & $5.2 a$ & 0.044 & $<0.001$ & ns \\
\hline \multirow[t]{2}{*}{ Number of leaves per plant (No.) } & $118.1 c$ & $142.3 a$ & $135.4 \mathrm{~b}$ & $146.4 a$ & 0.042 & 0.007 & ns \\
\hline & \multicolumn{7}{|c|}{ Dry season planting at $2^{\text {nd }}$ evaluation } \\
\hline Number of main branches per plant (No.) & $1.3 a$ & $1.3 a$ & $1.2 \mathrm{a}$ & $1.3 a$ & ns & ns & ns \\
\hline Length of main branches $(\mathrm{cm})$ & $78.6 \mathrm{~b}$ & $87.5 a$ & $86.3 a$ & $82.9 a b$ & $<0.001$ & ns & ns \\
\hline Number of secondary branches per plant (No.) & $6.9 \mathrm{~b}$ & $7.3 b$ & $8.3 a$ & $8.5 a$ & 0.006 & ns & ns \\
\hline Number of leaves per plant (No.) & $194.3 d$ & $216.9 c$ & 226.9b & $237.6 a$ & $<0.001$ & $<0.001$ & ns \\
\hline
\end{tabular}

Note. Values in the lines followed by the same letter are not significantly different at $\mathrm{p} \leq 0.05$ according to the LSD test. ns: not significant. ${ }^{(1)}$ Control $=$ without PBZ application, PBZ-10 = application of $100 \mathrm{~g} \cdot$ ha $^{-1}$ PBZ at 10 DASNF, PBZ-25 = application of $100 \mathrm{~g} \cdot$ ha $^{-1}$ PBZ at 25 DASNF, PBZ-10 + $25=$ application of $100 \mathrm{~g} \cdot$ ha-1 PBZ at 10 plus 25 DASNF. 


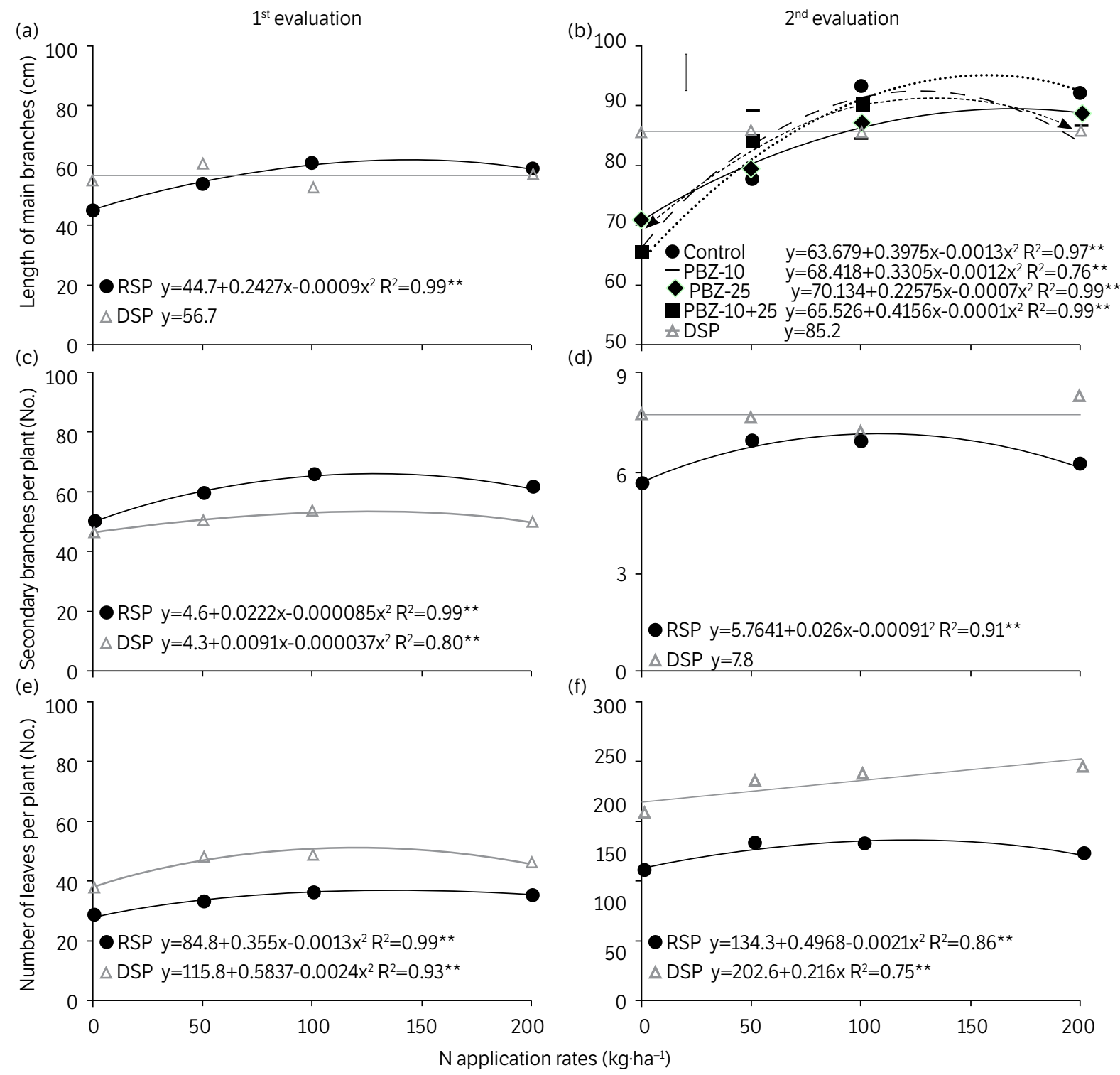

Figure 2. Length of main branches $(a, b)$, number of secondary branches per plant $(c, d)$ and number of leaves per plant (e, $f)$ in two evaluation times ( $1^{\text {st }}$ and $2^{\text {nd }}$ evaluations: 10 and 30 DALA) of sweet potato in response to $\mathrm{N}$ rates during two planting seasons.

Note. Average of two planting seasons (2017/18 and 2018/19). RSP: rainy season planting; DSP: dry season planting. Vertical bars represent the least significant difference at $p \leq 0.05$ according to the LSD test. ${ }^{* *} p \leq 0.01$.

At the second evaluation (30 DALA), the length of the branches in the planting of the rainy season was influenced by the $\mathrm{PBZ} \times \mathrm{N}$ rate interaction, but in the planting of the dry season, only the $\mathrm{PBZ}$ affected this variable (Table 1 ). In the rainy season, $\mathrm{N}$ rates increased the length of the branches in a quadratic manner in all treatments (Fig. 2b). In the absence of $\mathrm{N}$ fertilization, the branch length did not differ among the PBZ treatments. However, with the supply of rates between 100 and $200 \mathrm{~kg} \cdot \mathrm{ha}^{-1} \mathrm{~N}$, the PBZ-10 and PBZ-10 + 25 treatments showed branches, on average, 9\% shorter than the control (Fig. 2b). The PBZ-10 + 25 treatment resulted in plants with shorter branches due to the decrease in the initial growth of the branch caused by the first PBZ application at 10 DASNF (Table 1 and Fig. 2b). These results indicate that the early application of PBZ can interrupt the activity of gibberellic acid and reduce the length of the branches (Mabvongwe et al. 2016; Rademacher 2015). The reduction in the vegetative growth of plants can increase the translocation of photoassimilates from the shoot to the storage roots and increase the sweet potato yield (Chen et al. 2012; Njiti et al. 2013). 
In the two planting seasons, the number of secondary branches per plant at the first evaluation (10 DALA) was influenced by both the isolated factors studied (Table 1). At the second evaluation (30 DALA) in the rainy season, the number of secondary branches was affected by both factors, but, in the dry season, there was only the influence of PBZ on this variable. At both evaluation periods of the two planting seasons, the numbers of secondary branches of the control and PBZ-10 treatments were lower than the PBZ-10 + 25 treatment (Table 1). The increase in the number of secondary branches in the treatment with two PBZ applications occurred because the inhibition of the gibberellin synthesis by this product can increase the endogenous levels of cytokinin, and stimulate the development of axillary buds in the plants (Izumi et al. 1988).

At the two evaluations of the rainy season (10 and 30 DALA), the number of secondary branches per plant increased by $30 \%$ up to the rate of $130 \mathrm{~kg} \cdot \mathrm{ha}^{-1} \mathrm{~N}$ (Fig. $2 \mathrm{c}$ and $2 \mathrm{~d}$ ), but, in the dry season, there was an increase of $13 \%$ up to $122 \mathrm{~kg} \cdot \mathrm{ha}^{-1}$ $\mathrm{N}$ only at the first evaluation period (10 DALA) (Fig. 2c). These results reinforce the effect of $\mathrm{N}$ on the vegetative growth of plants. However, the excessive vegetation of the shoot competes with the development of storage roots, which can decrease the sweet potato yield (Fernandes et al. 2018; 2020).

At the first evaluation (10 DALA), the number of leaves per plant was affected only by the $\mathrm{N}$ rates in the rainy season and by the isolated factors in the dry season (Table 1). In the dry season, the number of leaves per plant of the PBZ-10 and PBZ-10 + 25 treatments did not differ; however, it was $22 \%$ greater than the control treatment. In the rainy and dry seasons, the number of leaves per plant at the first evaluation increased up to 136 and $121 \mathrm{~kg} \cdot \mathrm{ha}^{-1} \mathrm{~N}$, respectively (Fig. 2e). In both planting seasons, the number of leaves per plant at the second evaluation (30 DALA) was influenced by the isolated factors (Table 1). In both planting seasons, the number of leaves per plant was higher in the PBZ-10 + 25 treatment; however, in the rainy season planting this treatment did not differ from the PBZ-10 treatment (Table 1). As it happened in this study, the use of inhibitors of GA synthesis in potatoes (Solanum tuberosum L) also stimulated the development of new shoots (Opatrná et al. 1997). In the present study, the treatment with two sequential PBZ applications (PBZ-10 + 25) increased the number of secondary branches in both planting seasons, and this reflected in plants with a greater number of leaves (Table 1). At the second evaluation of the rainy season planting, the $\mathrm{N}$ fertilization increased the number of leaves per plant up to $118 \mathrm{~kg} \cdot \mathrm{ha}^{-1} \mathrm{~N}$, but, in the dry season planting, the increase in the number of leaves was linear (Fig. 2f).

The final plant population was not affected by the treatments during the rainy season and averaged 24,361 plants per hectare (Table 2) (Fig. 3a). In the dry season, only the $\mathrm{N}$ rates affected the final plant population. The application of rates above $44 \mathrm{~kg} \cdot \mathrm{ha}^{-1} \mathrm{~N}$ reduced the final plant population by up to $40 \%$ (Fig. 3a), possibly due to the lack of rainfall (Fig. 1), which increased the concentrations of salts in the soil. The increase in soil salinity depends of the fertilizer used and the amount applied, and the saline potential is all the greater the drier the soil. Thus, the lack of rain and the high $\mathrm{N}$ rates applied in the planting furrow together with $90 \mathrm{~kg} \cdot \mathrm{ha}^{-1} \mathrm{~K}_{2} \mathrm{O}$ as potassium chloride potentiated this effect in the dry season.

The shoot DM yield during the rainy and dry season plantings was affected by the isolated factors (Table 2). The PBZ-10 + 25 treatment showed a higher shoot DM yield during both the planting seasons; however, in the rainy season planting, this treatment did not differ from the PBZ-10 treatment (Table 2). The increase in the shoot DM yield of the treatment with two PBZ applications reflects the greater number of vegetative structures. The sequential application of PBZ (10 plus 25 DASNF) broke the apical dominance of the branches and stimulated the emission of new secondary branches and leaves, which resulted in higher shoot DM yield. The application of PBZ inhibits the synthesis of GA in plants, but also increases that of cytokinin (Desta and Amare 2021), which is responsible for regulating cell division, apical dominance and promoting the growth of new structures (Taiz et al. 2016) as was verified in the PBZ-10 + 25 treatment. The contents of abscisic acid (ABA) and phytol in the leaves (both beneficial for growth) are also increased by the PBZ application, and higher leaf concentrations of ABA help in protection against environmental stress (Desta and Amare 2021). In the rainy season, the $\mathrm{N}$ fertilization linearly increased the shoot DM yield by $99 \%$, while in the dry season the increase in shoot DM yield was of $11 \%$ and occurred only up to the estimated rate of $90 \mathrm{~kg} \cdot \mathrm{ha}^{-1} \mathrm{~N}$ (Fig. 3b). Despite, the plants from dry season had presented higher shoot DM yield regardless of N fertilization; in this study, the effect of $\mathrm{N}$ fertilization in promoting vegetative growth of sweet potatoes were greater in the rainy season (Table 2 and Fig. 3b). 
Table 2. Final plant population, dry matter (DM) yield of the shoot, storage roots, and whole plant, harvest index, $\mathrm{N}$ concentration in plant parts, $\mathrm{N}$ uptake, $\mathrm{N}$ removal, and fresh storage root yield of sweet potato in response to the application of PBZ and $\mathrm{N}$ rates during two planting seasons. Average of two planting seasons (2017/18 and 2018/19).

\begin{tabular}{|c|c|c|c|c|c|c|c|}
\hline \multirow{3}{*}{ Variables } & \multicolumn{4}{|c|}{ Time of PBZ application ${ }^{(1)}$} & \multicolumn{3}{|c|}{ ANOVA $(P>F)$} \\
\hline & Control & PBZ-10 & PBZ-25 & PBZ-10 + 25 & PBZ & N rate & $\mathrm{PBZ} \times \mathrm{N}$ \\
\hline & \multicolumn{7}{|c|}{ Rainy season planting } \\
\hline Final plant population (plants $\cdot$ ha $^{-1}$ ) & 23,675 & 24,408 & 24,387 & 24,975 & ns & ns & ns \\
\hline Shoot DM yield $\left(\mathrm{kg} \cdot \mathrm{ha}^{-1}\right)$ & $1748 b$ & $1997 a$ & $1732 b$ & $2183 a$ & $<0.001$ & $<0.001$ & ns \\
\hline Storage root DM yield $\left(\mathrm{kg} \cdot \mathrm{ha}^{-1}\right)$ & $3425 b$ & $4040 a$ & $3551 b$ & $4071 a$ & $<0.001$ & $<0.001$ & ns \\
\hline Whole plant DM yield $\left(\mathrm{kg} \cdot \mathrm{ha}^{-1}\right)$ & $5174 b$ & $6037 a$ & $5284 b$ & $6254 a$ & $<0.001$ & $<0.001$ & ns \\
\hline Harvest index & 0.68 & 0.67 & 0.70 & 0.68 & ns & ns & ns \\
\hline Fresh storage root yield $\left(\mathrm{kg} \cdot \mathrm{ha}^{-1}\right)$ & $14,542 c$ & $16,676 b$ & $14,943 c$ & $17,361 a$ & 0.004 & 0.006 & ns \\
\hline Shoot $\mathrm{N}$ concentration $\left(\mathrm{g} \cdot \mathrm{kg}^{-1}\right)$ & $17.0 a$ & $16.6 a b$ & $17.3 a$ & $15.7 \mathrm{~b}$ & 0.024 & $<0.001$ & ns \\
\hline Storage root $\mathrm{N}$ concentration $\left(\mathrm{g} \cdot \mathrm{kg}^{-1}\right)$ & 5.0 & 5.2 & 4.6 & 4.3 & ns & $<0.001$ & ns \\
\hline N uptake $\left(\mathrm{kg} \cdot \mathrm{ha}^{-1}\right)$ & $46.9 b$ & $54.3 a$ & $46.9 b$ & $52.7 a b$ & 0.02 & $<0.001$ & ns \\
\hline \multirow[t]{2}{*}{$\mathrm{N}$ removal $\left(\mathrm{kg} \cdot \mathrm{ha}^{-1}\right)$} & $17.4 b$ & $21.4 a$ & $16.6 b$ & $17.3 b$ & 0.01 & $<0.001$ & ns \\
\hline & \multicolumn{7}{|c|}{ Dry season planting } \\
\hline Final plant population (plants $\cdot \mathrm{ha}^{-1}$ ) & 11,417 & 12,098 & 11,851 & 11,193 & ns & $<0.001$ & ns \\
\hline Shoot DM yield $\left(\mathrm{kg} \cdot \mathrm{ha}^{-1}\right)$ & $4447 c$ & $4556 c$ & $4972 b$ & $5314 a$ & $<0.001$ & $<0.001$ & ns \\
\hline Storage root DM yield $\left(\mathrm{kg} \cdot \mathrm{ha}^{-1}\right)$ & $2469 a b$ & $2587 a$ & $2291 b$ & $2304 b$ & $<0.001$ & $<0.001$ & ns \\
\hline Whole plant DM yield $\left(\mathrm{kg} \cdot \mathrm{ha}^{-1}\right)$ & $6917 b$ & $7144 b$ & 7264ab & $7619 a$ & $<0.001$ & $<0.001$ & ns \\
\hline Harvest index & $0.35 a$ & $0.36 a$ & $0.31 b$ & $0.30 \mathrm{~b}$ & $<0.001$ & $<0.001$ & ns \\
\hline Fresh storage root yield $\left(\mathrm{kg} \cdot \mathrm{ha}^{-1}\right)$ & $10,180 \mathrm{~b}$ & $10,700 a$ & $9,271 c$ & $9,303 c$ & $<0.001$ & $<0.001$ & ns \\
\hline Shoot $\mathrm{N}$ concentration $\left(\mathrm{g} \cdot \mathrm{kg}^{-1}\right)$ & 17.2 & 17.8 & 18.4 & 18.7 & ns & 0.007 & ns \\
\hline Storage root $\mathrm{N}$ concentration $\left(\mathrm{g} \cdot \mathrm{kg}^{-1}\right)$ & 8.0 & 8.2 & 7.3 & 8.0 & ns & $<0.001$ & ns \\
\hline N uptake $\left(\mathrm{kg} \cdot \mathrm{ha}^{-1}\right)$ & $94 b$ & $101 b$ & 107b & $117 a$ & $<0.001$ & $<0.001$ & ns \\
\hline $\mathrm{N}$ removal $\left(\mathrm{kg} \cdot \mathrm{ha}^{-1}\right)$ & 17.7 & 20.0 & 15.5 & 17.7 & ns & $<0.001$ & ns \\
\hline
\end{tabular}

Note. Values in the lines followed by the same letter are not significantly different at $\mathrm{p} \leq 0.05$ according to the LSD test. ns: not significant. ${ }^{(1)}$ Control $=$ without PBZ application, PBZ-10 = application of $100 \mathrm{~g} \cdot \mathrm{ha}^{-1}$ PBZ at 10 DASNF, PBZ-25 = application of $100 \mathrm{~g} \cdot \mathrm{ha}^{-1}$ PBZ at 25 DASNF, PBZ-10 $+25=$ application of $100 \mathrm{~g} \cdot \mathrm{ha}^{-1}$ PBZ at 10 plus 25 DASNF.

The DM yield of the storage roots during the two planting seasons was affected by the PBZ and N rates alone (Table 2). In the rainy season, the DM of the storage roots of the PBZ-10 and PBZ-10 + 25 treatments did not differ and was $16 \%$ higher than the other treatments. These results indicate that the increase in the vegetative growth promoted by the early PBZ application was not excessive, as it also increased the DM of the storage roots (Tables 1 and 2). However, in the dry season the treatments with late $\mathrm{PBZ}$ applications reduced the $\mathrm{DM}$ of the storage roots compared to the treatment with only one early application of $\mathrm{PBZ}$, which indicates that the early application of PBZ is more interesting to stimulate the development of the storage roots.

Nitrogen fertilization increased the DM of the storage roots by $30 \%$ up to the rate of $134 \mathrm{~kg} \cdot \mathrm{ha}^{-1} \mathrm{~N}$ in the rainy season, and linearly reduced it by $68 \%$ in the dry season (Fig. 3c). This indicates that, in the rainy season, the $\mathrm{N}$ promoted the development of the storage roots, i.e., there was an adequate growth of the shoot that resulted in greater supply and distribution of photoassimilates for the storage roots, interfering positively in the root DM produced (Duan et al. 2019; Pushpalatha et al. 2018). However, in the dry season the increase in the $\mathrm{N}$ supply impaired the development of storage roots because it reduced their number and mean weight (data not shown). Therefore, the lower development of storage roots in response to $\mathrm{N}$ application during the dry season was not a result of the overgrowth of vegetative organs as suggested by other studies (Fernandes et al. 2018; 2020; Oliveira et al. 2006), since $\mathrm{N}$ fertilization in the dry season increased the shoot DM yield by only $11 \%$ (Fig. 3b).

The whole plant DM yield was influenced by the isolated factors in both the planting seasons (Table 2). In the rainy season, the PBZ-10 and PBZ-10 + 25 treatments had an increase of $18 \%$ in the whole plant DM, which was a reflection of the positive effect of these treatments on the shoot DM. However, in the dry season, the plants treated with two sequential PBZ applications accumulated more DM than the plants of the control and PBZ-10 treatments. The higher DM of the plants in the treatment with two PBZ applications is the result of the excessive shoot growth. The $\mathrm{N}$ fertilization increased the whole plant $\mathrm{DM}$ up to the highest $\mathrm{N}$ rate studied in the rainy season, and, in the dry season, it linearly reduced the whole plant DM, mainly due to the decrease caused in the DM of the storage roots (Fig. $3 \mathrm{c}$ and $3 \mathrm{~d}$ ). 
(a)

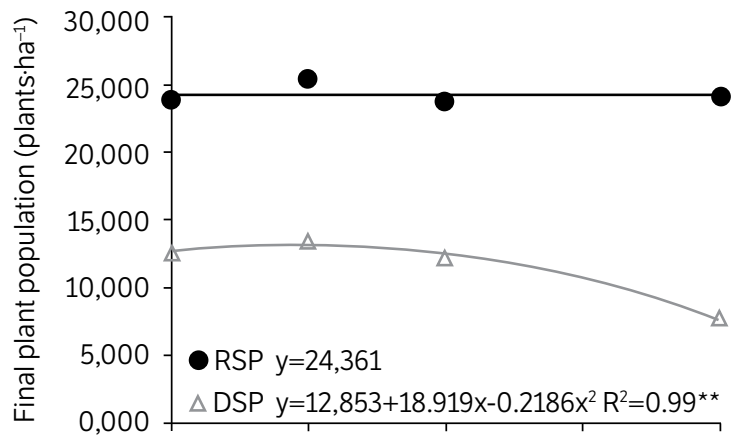

(c)

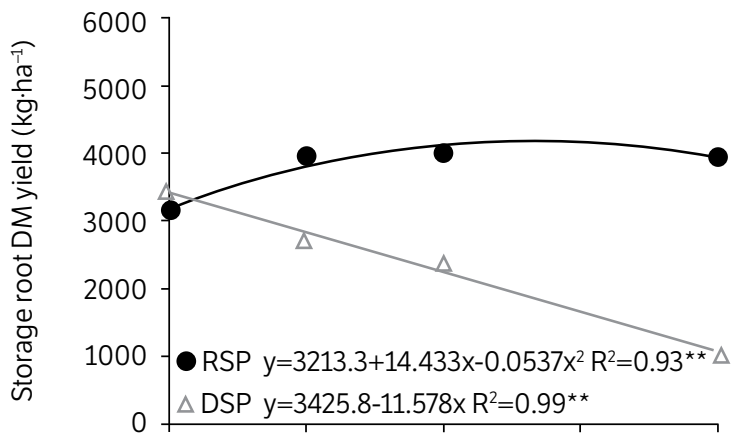

(e)

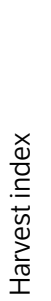

(b)

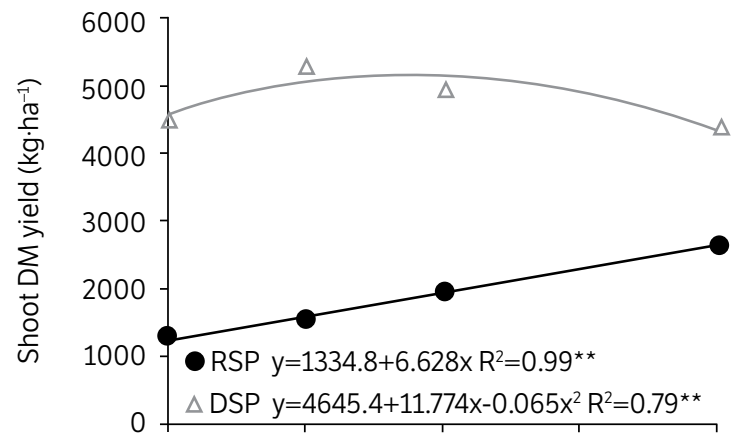

(d)

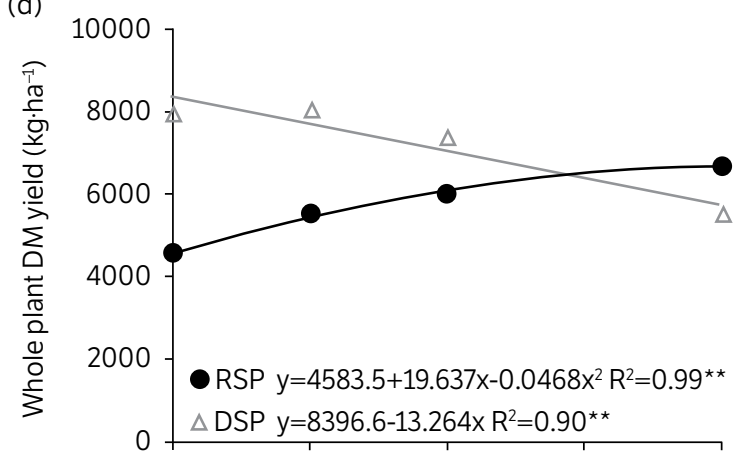

(f)

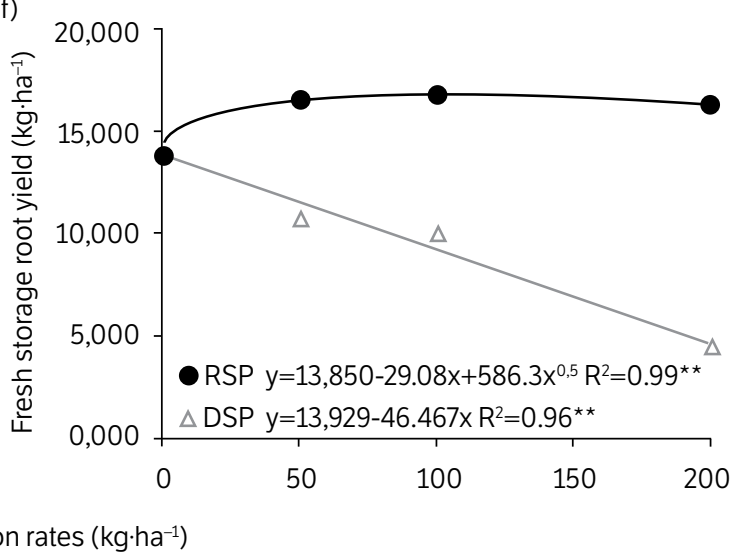

Figure 3. Final plant population (a), dry matter (DM) yield of the shoot (b), storage roots (c), and whole plant (d), harvest index (e), and fresh storage root yield ( $\mathrm{f}$ ) of sweet potato in response to $\mathrm{N}$ rates during two planting seasons.

Note. Average of two planting seasons (2017/18 and 2018/19). RSP: rainy season planting; DSP: dry season planting. ${ }^{* *} \mathrm{p} \leq 0.01$.

There was no influence of the factors studied on the HI in the rainy season, which was on average 0.68 (Table 2), i.e., above the minimum value of 0.50 suggested for root crops (Peixoto et al. 2005). In the dry season, both studied factors affected the HI. In the dry season, the PBZ-25 and PBZ-10 + 25 treatments had their HIs reduced, which indicates that in these treatments the PBZ reduced the development of the storage root. In general, the HI in the dry season was between 0.30 and 0.36 , i.e., below what is recommended for root crops (Peixoto et al. 2005). The $\mathrm{N}$ fertilization linearly reduced the $\mathrm{HI}$ of the plants in the dry season (Fig. 3e), but the reduction in the HI was not because $\mathrm{N}$ caused an overgrowth of the plant shoot, as suggested in other studies (Fernandes et al. 2018; 2020; Oliveira et al. 2006), but because N reduced the development of storage roots (Fig. 3c). In the dry season, HI was lower than in the rainy season, even in the absence of $\mathrm{N}$ fertilization, indicating that in the dry season the preferred metabolic sink of the plants was the shoot (Fig. 3e). Unlike the rainy season, during almost all the first 50 days of sweet potato cultivation in the dry season, the minimum temperature in the two years was $\leq 15^{\circ} \mathrm{C}$, which is limiting for the growth of storage roots (Ravi et al. 2009; Villordon et al. 2009), and 
the average precipitation in this period of storage roots formation was only $38 \mathrm{~mm}$ (Fig. 1), which reflected in low storage root DM yield and HI (Table 2, Fig. 3c and 3e). Drought stress in the early stage of sweet potatoes reduces the number of storage roots, delays the development of the formed storage roots and reduces storage root yield (Solis et al. 2014). However, after 80 days of cultivation in the dry season, there was greater precipitation and maximum temperatures during most days were $\geq 30^{\circ} \mathrm{C}$ (Fig. 1), i.e., temperatures favorable to the sweet potato shoot development (Ravi et al. 2009; Villavicencio et al. 2007), which contributed to a high shoot DM yield and a low HI, since the storage roots did not develop well (Table 2, Fig. 3b, 3c, and 3e).

In both planting seasons, the fresh storage root yield was influenced by the PBZ and $\mathrm{N}$ rates (Table 2). In the rainy season, the PBZ-10 + 25 treatment showed the highest root yield, the PBZ-10 treatment showed intermediate root yield, while the lowest root yield occurred in the control and PBZ-25 treatments. However, in the dry season, the PBZ-10 treatment was the most productive (Table 2). These results indicate that the application of PBZ only at 10 DASNF benefited the yield of fresh roots from both planting seasons because it increased the development of the storage organ (Table 2). Paclobutrazol application promotes several physiological modifications in the plants, including the increase in the carbohydrates partitioning to the storage organ (Desta and Amare 2021), whose mechanism is associated with PBZ stimulated low gibberellin level in the tissues of the storage organ that increases its sink activity (Tekalign and Hammes 2005).

In the rainy season, the $\mathrm{N}$ fertilization increased the fresh storage root yield up to $50 \mathrm{~kg} \cdot \mathrm{ha}^{-1} \mathrm{~N}$, and at the highest $\mathrm{N}$ rates the yield remained stable (Fig. 3f). However, in the dry season, the supply of $\mathrm{N}$ linearly reduced the fresh root yield by $67 \%$, which shows that in this growing season the $\mathrm{N}$ fertilization does not benefit the storage root yield of sweet potatoes. According to Oliveira et al. (2006), the excess of $\mathrm{N}$ increases the vegetative growth at the expense of the development of storage roots. However, in this study, $\mathrm{N}$ decreased the yield of fresh storage roots only in the dry season, and this reduction was not the expense of an overgrowth of the shoot promoted by $\mathrm{N}$. Thus, this study indicates that, for cultivation in the rainy season, the rates of $\mathrm{N}$ recommended by the Brazilian fertilization technical bulletins, which vary from 20 to $60 \mathrm{~kg} \cdot \mathrm{ha}^{-1} \mathrm{~N}$, are still adequate (Casali 1999; Lorenzi et al. 1997; Silva et al. 2002).

The $\mathrm{N}$ concentration in the shoot was influenced by both factors studied in the rainy season, and only by the $\mathrm{N}$ rates in the dry season (Table 2). In the rainy season, the treatment with two applications of PBZ showed a shoot $\mathrm{N}$ concentration 8\% lower than that of the control and PBZ-25 treatments, possibly due to the dilution effect, since the shoot biomass of this treatment was higher (Table 2). The $\mathrm{N}$ fertilization linearly increased the levels of $\mathrm{N}$ in the plant shoot during the rainy season, whereas in the dry season the increases occurred only up to the estimated rate of $178 \mathrm{~kg} \cdot \mathrm{ha}^{-1} \mathrm{~N}$ (Fig. 4a). In both seasons, it appears that the application of $\mathrm{N}$ fertilizer increased the $\mathrm{N}$ concentration in the sweet potato shoot, as was also observed in the studies conducted by Pushpalatha et al. (2018) and Kakabouki et al. (2020).

There was an effect only of the $\mathrm{N}$ fertilization on the $\mathrm{N}$ concentrations of the storage roots in both planting seasons (Table 2). In both planting seasons, the $\mathrm{N}$ fertilization increased the concentrations of $\mathrm{N}$ in the storage roots up to the highest $\mathrm{N}$ rate studied, but in the rainy season, the increments in the levels of this nutrient were greater (Fig. $4 \mathrm{~b}$ ). In the two planting seasons, the uptake of $\mathrm{N}$ by sweet potatoes was influenced by both factors studied (Table 2). However, the $\mathrm{N}$ removal was influenced by the $\mathrm{PBZ}$ and $\mathrm{N}$ rates in the rainy season planting, and only by the $\mathrm{N}$ rates in the dry season planting. In the rainy season planting, the PBZ-10 treatment increased the uptake and removal of $\mathrm{N}$ by the plants, but in the dry season, there was an increase in the $\mathrm{N}$ uptake only when two PBZ applications were made. The increase in $\mathrm{N}$ uptake and removal in response to PBZ application is a result of the increase in the plant biomass and $\mathrm{N}$ concentrations in the plant tissues, especially in the shoot.

The $\mathrm{N}$ fertilization linearly increased the uptake and removal of $\mathrm{N}$ by sweet potatoes when planting in the rainy season; however, in the dry season the uptake and removal of $\mathrm{N}$ increased up to 97 and $65 \mathrm{~kg} \cdot \mathrm{ha}^{-1} \mathrm{~N}$, respectively (Fig. 4c-d). The results of this study indicate that the application of high $\mathrm{N}$ rates unnecessarily increases the $\mathrm{N}$ uptake and removal by the plants, and this negative effect is greater in the dry season planting, where the $\mathrm{N}$ supply does not benefit the sweet potato yield. In the rainy season planting, the maximum $\mathrm{N}$ uptake and removal was 74 and $26.4 \mathrm{~kg} \cdot \mathrm{ha}^{-1} \mathrm{~N}$, respectively. However, in the dry season the maximum amounts of $\mathrm{N}$ taken up and removed were 117 and $21 \mathrm{~kg} \cdot \mathrm{ha}{ }^{-1} \mathrm{~N}$, i.e., during the dry season, there was a high $\mathrm{N}$ accumulation in the plant shoot (Fig. 4c). Despite this, the amounts of $\mathrm{N}$ taken up during the dry season 
were close to the values of 128 and $129 \mathrm{~kg} \cdot \mathrm{ha}^{-1} \mathrm{~N}$ mentioned by Fernandes et al. (2018) and Miranda et al. (1995). However, the removal values of $\mathrm{N}$ in this study were lower than those reported by Fernandes et al. $(2018 ; 2020)$ due to the lower yield of fresh storage roots and storage root biomass obtained in this study.

(a)

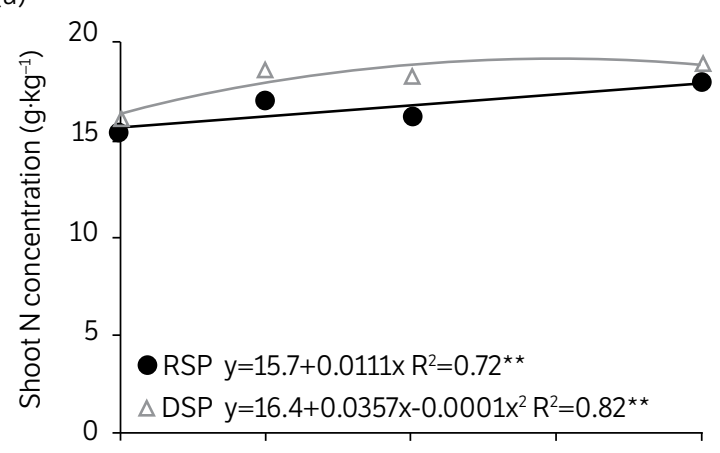

(c)

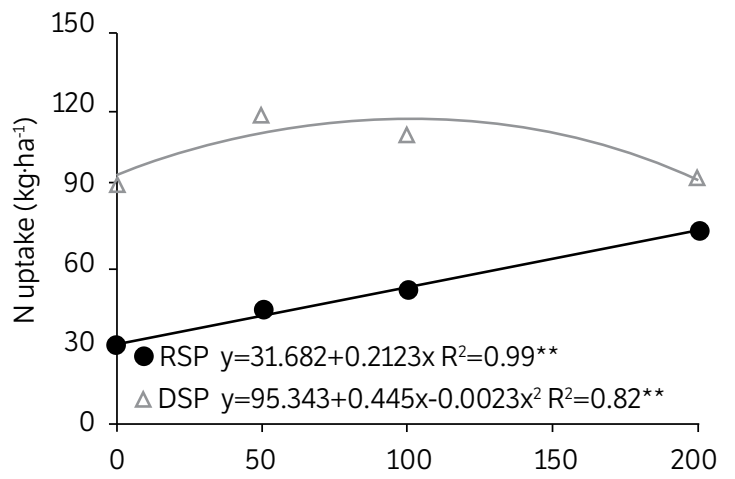

(b)

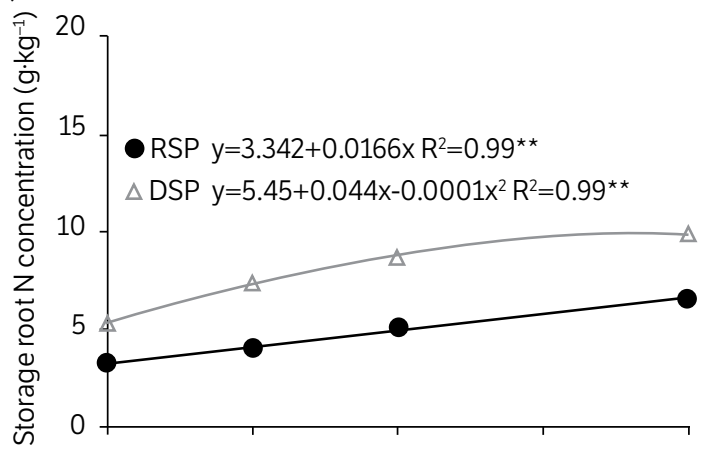

(d)

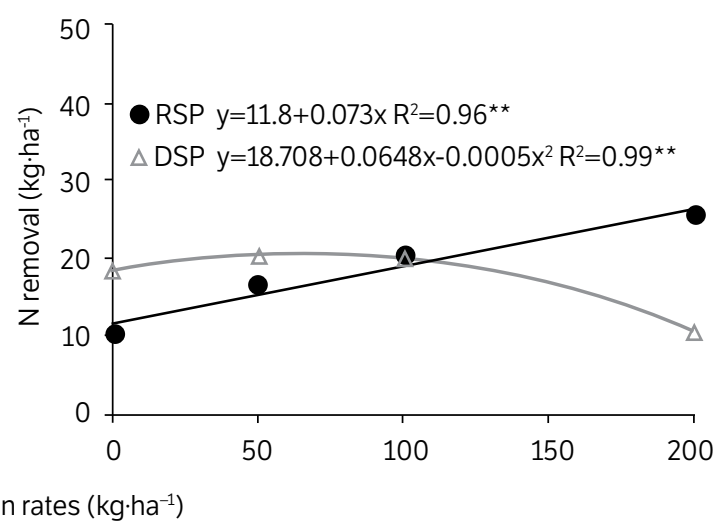

Figure 4. Nitrogen concentration in the shoot (a) and storage roots (b), $\mathrm{N}$ uptake (c), and $\mathrm{N}$ removal (d) by sweet potato in response to $\mathrm{N}$ rates during two planting seasons.

Note. Average of two planting seasons (2017/18 and 2018/19). RSP: rainy season planting; DSP: dry season planting. ${ }^{* *} \mathrm{p} \leq 0.01$.

\section{CONCLUSION}

Paclobutrazol application temporarily reduced the length of the main branches of sweet potato planted in the rainy season, but it did not reduce the shoot biomass of plants, regardless of the planting season. A single application of PBZ at 10 DASNF increased the yield of fresh storage roots in the two planting seasons, but during the rainy season, the increases were greater when two applications were carried out.

In the rainy season, the application of $50 \mathrm{~kg} \cdot h \mathrm{a}^{-1} \mathrm{~N}$ was sufficient to achieve the maximum yield of fresh storage roots, and higher $\mathrm{N}$ rates unnecessarily increase the vegetative growth, uptake, and removal of $\mathrm{N}$. In the dry season, the $\mathrm{N}$ fertilization increased the $\mathrm{N}$ uptake without benefits for the storage root yield.

\section{AUTHORS' CONTRIBUTION}

Conceptualization: Ribeiro, N. P. and Fernandes, A. M.; Methodology: Ribeiro, N. P., Silva, R. M., Pelvine, R. A. and Assunção, N. S.; Investigation: Ribeiro, N. P., Silva, R. M., Pelvine, R. A. and Assunção, N. S.; Writing - Original Draft: Ribeiro, N. P.; Writing - Review and Editing: Fernandes, A. M.; Funding Acquisition: Fernandes, A. M.; Supervision: Fernandes, A. M. 


\section{DATA AVAILABILITY STATEMENT}

All dataset were generated or analyzed in the current study.

\section{FUNDING}

Coordenação de Aperfeiçoamento de Pessoal de Nível Superior

[https://doi.org/10.13039/501100002322]

Grant No. 88882.433039/2019-01

Conselho Nacional de Desenvolvimento Científico e Tecnológico

[https://doi.org/10.13039/501100003593]

Grant No: 303149/2020-5

\section{ACKNOWLEDGMENTS}

Not applicable.

\section{REFERENCES}

[Brazil]. Ministério da Agricultura, Pecuária e Abastecimento. (2021). Sistema de Agrotóxicos Fitossanitário. Ingrediente ativo: produtos formulados. [Accessed Mar. 22, 2021]. Available at: http://agrofit.agricultura.gov.br/agrofit_cons/principal_agrofit_cons

Casali, V. W. (1999). Batata-doce. In A. C., Ribeiro, P. T. G., Guimarães and V. H. Alvarez (Eds.), Recomendações para o uso de corretivos e fertilizantes em Minas Gerais: 5a Aproximação (p. 180). Viçosa: CFSEMG.

Chen, X. G., Li, H. M., Zhang, A. J., Shi, X. M., Tang, Z. H., Wei, M. and Shi, C. Y. (2012). Effect of paclobutrazol under different N-application rates on photosynthesis and starch accumulation in edible sweet potato. Acta Agronomica Sinica, 38, 1728-1733. Chinese.

Desta, B. and Amare, G. (2021). Paclobutrazol as a plant growth regulator. Chemical and Biological Technologies in Agriculture, 8, 1. https://doi.org/10.1186/s40538-020-00199-z

Duan, W., Zhang, H., Xie, B., Wang, B. and Zhang, L. (2019). Impacts of nitrogen fertilization rate on the root yield, starch yield and starch physicochemical properties of the sweet potato cultivar Jishu 25. PLOS One, 14, e0221351. https://doi.org/10.1371/journal.pone.0221351 Espindula, M. C., Rocha, V. S., Grossi, J. A. S., Souza, M. A., Souza, L. T. and Favarato, L. F. (2009). Use of growth retardants in wheat. Planta Daninha, 27, 379-387. https://doi.org/10.1590/S0100-83582009000200022

Fernandes, A. M., Assunção, N. S., Ribeiro, N. P., Gazola, B. and Silva, R. M. (2020). Nutrient uptake and removal by sweet potato fertilized with green manure and nitrogen on sandy soil. Revista Brasileira de Ciência do Solo, 44, e0190127. https://doi.org/10.36783/18069657rbcs20190127

Fernandes, A. M., Campos, L. G., Senna, M. S., Silva, C. L. and Assunção, N. S. (2018). Yield and nitrogen use efficiency of sweet potato in response to cover crop and nitrogen management. Agronomy Journal, 110, 2004-2015. https://doi.org/10.2134/agronj2017.12.0721

Ferreira, D. F. (2011). Sisvar: a computer statistical analysis system. Ciência e Agrotecnologia, 35, 1039-1042. https://doi.org/10.1590/ S1413-70542011000600001 
Foloni, J. S. S., Corte, A. J., Corte, J. R. N., Echer, F. R., Tiritan, C. S. (2013). Adubação de cobertura na batata-doce com doses combinadas de nitrogênio e potássio. Semina: Ciências Agrárias, 34, 117-126. https://doi.org/10.5433/1679-0359.2013v34n117

Izumi, K., Nakagawa, S., Kobayashi, M., Oshio, H., Sakurai, A. and Takahashi, N. (1988). Levels of IAA, Cytokinins, ABA and ethylene in rice plants as affected by a gibberellin biosynthesis inhibitor, Uniconazole-P. Plant and Cell Physiology, 29, 97-104. https://doi.org/10.1093/ oxfordjournals.pcp.a077480

Kakabouki, I., Togias, T., Folina, A. E., Karydogianni, S., Zisi, C. and Bilalis, D. (2020). Evaluation of yield and nitrogen utilisation with urease and nitrification inhibitors in sweet potato crop (Ipomoea batatas L.). Folia Horticulturae, 32, 147-157. https://doi.org/10.2478/ fhort-2020-0014

Leonardo, F. A. P., Oliveira, A. P., Pereira, W. E., Silva, P. O. R., Barros, J. R. A. (2014). Rendimento da batata-doce adubada com nitrogênio e esterco bovino. Revista Caatinga, 27, 18-23.

Lorenzi, J. O., Monteiro, P. A., Miranda Filho, H. S. and van Raij, B. (1997). Raízes e tubérculos. In B. van Raij, H. Cantarella, J. A., Quaggio, and A. M. C. Furlani (Eds.), Recomendações de adubação e calagem para o Estado de São Paulo (p. 221-229) [Boletim Técnico 100]. Campinas: Instituto Agronômico.

Mabvongwe, O., Manenji, B. T., Gwazane, M. and Chandiposha, M. (2016). The effect of paclobutrazol application time and variety on growth, yield, and quality of potato (Solanum tuberosum L.). Advances in Agriculture, 2016, 1585463. https://doi.org/10.1155/2016/1585463

Malavolta, E., Vitti, G. C. and Oliveira, A. S. (1997). Avaliação do estado nutricional das plantas: princípios e aplicações. Piracicaba: Potafos.

Miranda, J. E. C., França, F. H., Carrijo, O. A., Souza, A. F., Pereira, W., Lopes, C. A. and Silva, J. B. C. (1995). A cultura da batata-doce. Brasília: Embrapa.

Njiti, V. N., Xia, Q., Tyler, L. S., Stewart, L. D., Tenner, A. T., Zhang, C., Alipoe, D., Chukwuma, F. and Gao, M. (2013). Influence of prohexadione calcium on sweetpotato growth and storage root yield. HortScience, 48, 73-76. https://doi.org/10.21273/HORTSCl.48.1.73

Oliveira, A. P., Moura, M. F., Nogueira, D. H., Chagas, N. G., Braz, M. S. S., Oliveira, M. R. T. and Barbosa, J. A. (2006). Produção de raízes de batata-doce em função do uso de doses de N aplicadas no solo e via foliar. Horticultura Brasileira, 24, 279-282. https://doi.org/10.1590/ S0102-05362006000300002

Oliveira, G. P., Siqueira, D. L., Salomão, L. C. C., Cecon, P. R. and Machado, D. L. M. (2017). Paclobutrazol and branch tip pruning on the flowering induction and quality of mango tree fruits. Pesquisa Agropecuária Tropical, 47,7-14. https://doi.org/10.1590/1983-40632016v4743861

Opatrná, J., Novák, P. and Opatrný, Z. (1997). Paclobutrazol stimulates bud regeneration in Solanum tuberosum L. primary explant cultures. Biologia Plantarum, 39, 151-158. https://doi.org/10.1023/A:1000385712937

Peixoto, J. R., Bernardes, S. R., Santos, C. M., Bonnas, D. S., Fialho, J. F. and Oliveira, J. A. (2005). Desempenho agronômico de variedades de mandioca mansa em Uberlândia, MG. Revista Brasileira de Mandioca, 18, $19-24$.

Pricinotto, L. F., Zucareli, C. (2014). Paclobutrazol no crescimento e desempenho produtivo da soja sob diferentes densidades de semeadura. Revista Caatinga, 27, 65-74.

Pushpalatha, M., Vaidya, P. H., Sunil, B. H. and Adsul, P. B. (2018). Influence of graded levels of nitrogen and potassium on root rhizosphere soil properties and yield of sweet potato (Ipomoea batatas. L.) in vertisols of Maharashtra. Journal of Pharmacognosy and Phytochemistry, 3, 2883-2886.

Rademacher, W. (2015). Plant growth regulators: backgrounds and uses in plant production. Journal of Plant Growth Regulation, 34, 845-872. https://doi.org/10.1007/s00344-015-9541-6

Ravi, V., Naskar, S. K., Makeshkumar, T., Babu, B. and Krishnan, B. S. P. (2009). Molecular physiology of storage root formation and development in sweet potato (Ipomoea batatas (L.) Lam.). Journal of Root Crops, 35, 1-27. 
Santos, H. G., Jacomine, P. K. T., Anjos, L. H. C., Oliveira, V. A., Lumbreras, J. F., Coelho, M. R., Almeida, J. A., Araujo Filho, J. C., Oliveira, J. B. and Cunha, T. J. F. (2018). Sistema brasileiro de classificação de solos. Brasília: Embrapa.

Santos Neto, A. R., Silva, T. O., Blank, A. F., Silva, J. O. and Araújo Filho, R. N. (2017). Produtividade de clones de batata doce em função de doses de nitrogênio. Horticultura Brasileira, 35, 445-52. https://doi.org/10.1590/s0102-053620170322

Silva, K. S. and Faria Junior, M. J. A. (2011). Uso de paclobutrazol como estratégia para redução do porte e da brotação lateral de plantas de tomateiro. Ciência e Agrotecnologia, 35, 539-546. https://doi.org/10.1590/S1413-70542011005000004

Silva, J. B. C., Lopes, C. A. and Magalhães, J. S. (2002). Cultura da batata-doce. In M. P. Cereda (Ed.), Agricultura: tuberosas amiláceas Latino Americanas (p. 448-504). São Paulo: Fundação Cargill.

Solis, J., Villordon, A., Baisakh, N., LaBonte, D. and Firon, N. (2014). Effect of drought on storage root development and gene expression profile of sweetpotato under greenhouse and field conditions. Journal of the American Society for Horticultural Science, 139, 317-324. https://doi.org/10.21273/JASHS.139.3.317

Taiz, L., Zeiger, E., Moller, I. M. and Murphy, A. (2016). Fisiologia e desenvolvimento vegetal. Porto Alegre: Artmed.

Tekalign T. and Hammes, P. S. (2005). Growth and biomass production in potato grown in the hot tropics as influenced by paclobutrazol. Plant Growth Regulation, 45, 37-46. https://doi.org/10.1007/s10725-004-6443-1

van Raij, B., Andrade, J. C., Cantarella, H. and Quaggio, J. A. (2001). Análise química para avaliação da fertilidade de solos tropicais. Campinas: Instituto Agronômico.

Villavicencio, L. E., Blankenship, S. M., Yencho, G. C., Thomas, J. F. and Raper, C. D. (2007). Temperature effect on skin adhesion, cell wall enzyme activity, lignin content, anthocyanins, growth parameters, and periderm histochemistry of sweetpotato. Journal of the American Society for Horticultural Science, 132, 729-738. https://doi.org/10.21273/JASHS.132.5.729

Villordon, A., Clark, C., Ferrin, D. and LaBonte, D. (2009). Using growing degree days, agrometeorological variables, linear regression, and data mining methods to help improve prediction of sweetpotato harvest date in Louisiana. HortTechnology, 19, 133-144. https:// doi.org/10.21273/HORTSCI.19.1.133 